\title{
Afetlere Sosyolojik Bakış ve Türkiye'de Afet Yazınına Kuramsal Bir Yaklaşım
}

\section{Sociological Glance to Disasters and A Theoretical Approach to Disaster Literature in Turkey}

\author{
Gaye Gökalp Y1lmaz ${ }^{\text {a,* }}$ \\ ${ }^{a}$ Dr. Öğr. Üyesi, Burdur Mehmet Akif Ersoy Üniversitesi, Fen-Edebiyat Fakültesi, Sosyoloji Bölümü, 15000, Burdur /Türkiye. \\ ORCID: 0000-0002-6304-3425
}

\section{MAKALE BİLGİS}

\section{Makale Geçmişi}

Başvuru tarihi: 02 Kasım 2020

Düzeltme tarihi: 29 Aralık 2020

Kabul tarihi: 07 Ocak 2021

Anahtar Kelimeler:
Afet
Afet Sosyolojisi
Fenomenoloji
Etnometodoloji

\section{ARTICLE INFO}

Article history:

Received 02 Novamber 2020

Received in revised form 29 December 2020

Accepted 07 January 2021

Keywords:
Disaster
Sociology of Disaster
Phenomenology
Ethnomethodology

ÖZ

$\mathrm{Bu}$ çalışma, afet çalışmalarını bu alana egemen olan doğa bilimleri açısından inceleyen ve afetlere yönelik klasik yaklaşımlara dayalı açıklamalara ek olarak, afet çalışmalarına birey ve toplum odaklı bakış açısıyla sosyolojik ve metodolojik katkılar sunmayı amaçlamaktadır. Türkiye'de temelde deprem ve sonrasında ihtiyaçların karşılanması ve depreme hazırlık bağlamında ele alınan afet çalışmaları, Türkçe literatürde sosyolojik açıdan sınırlı düzeyde tartışılmaktadır. Dolayısıyla, yalnızca deprem değil tüm afetlere yönelik bir yazın geliștirmek ve özellikle birey ve bireyin anlamlandırma ve "rutin olanı" yeniden inşa süreçlerine odaklanmak gereklidir. Bu bağlamda, afetlerin toplumsal boyutuna değinerek, toplumsal ve gündelik hayatın yani düzenin kesintiye uğramasına bağlı olarak toplumsal olanın, anlamların ve ilişkilerin yeniden inşa süreçlerine fenomenolojik ve etnometodolojik bakış açısıyla odaklanmak, afet yazınının sosyolojik boyutunu metodolojik anlamda daha güçlü kılacaktır.

\section{A B S T R A C T}

This study intends to provide sociological and methodological contributions which are focused on individual and society. to disaster studies, dominantly analyzed with natural sciences approach and classical disaster appaoraches, . In Turkey, disasters that are focused on earthquake studies and mainly focus on fullfilling necessities after earthquake and preparations to earthquakes are limitedly analyzed within sociological regards. Therefore, it is required to establish not only to earthquakes but also to all disasters' literature and to focus on individual and individuals"'meaning" and reconstruction of "routine". Within this regard, dealing with sociological aspect of disasters and phenomenological and ethnomethodological focusing on "meaning" and "reconstruction" process will make sociological aspect of disaster literature more robust.

\section{Giriș}

Toplumların karşılaştıkları en önemli ve en derin etkileri yaratan afetler, her ne kadar temel olarak yer bilimleri, çevre bilimleri, jeoloji gibi doğa bilimlerinin konusu olsa da yaşanılan doğal afetler sonrası toplumların yaşadıkları ağır hasarlar sonucunda düzenin ve rutinin bozulması, yeniden düzen kurulması, toplumsal iş birliği ve dayanışma süreçleri, sosyolojinin ve özel olarak afet sosyolojisinin konusunu oluşturmaktadır. Afetlere ilişkin sosyal bilim yazınında ise sıklıkla afetler sonrası yaşanan toplumsal travmaları ele alan psiko-sosyal çalışmalar gerçekleştirilmekte ve toplumların acıyla baş etme ve yeniden ayağa kalkma stratejileri psikolojik boyutta ele alınmaktadır.

Sosyolojinin konusu olarak afetler ise temel olarak insan etkileşimlerini temel almaktadır. Doğal afetlerin, insan ve teknolojik kaynaklı yaşanan felaketlerin farklı kavramsallaştırmalar çerçevesinde incelenmesi ve farklı disiplinlerin inceleme konusu olması, afet kavramının tanımlanmasını farklılaştırmakta ve kimi zaman güçleştirmektedir. Afetlerin tanımlanmasında ayrıca fiziksel zarar temelinde yapılan tanımlamalar da aynı şekilde bireysel ve toplumsal etkileri ikinci plana atmakta ve afetlere ilişkin çalışma ve analizlerde yer bilimi, coğrafya, fizik, kimya ve mühendislik gibi pozitif bilimlerin egemenliğini ön

\footnotetext{
* Sorumlu yazar/Corresponding author.

e-posta: gayegokalp@gmail.com
} 
plana çıkarmaktadır. Oysaki, yaşanılan her bir afet sonrası toplumsal hayata dair ve toplumsallașmaya dair yeni örüntüler yaşanmakta ve her bir afetin kendine ait sosyolojisi oluşmaktadır. Bu çalışma da afetlerin sosyal bilim yazınında ele alınma biçimlerine sosyolojik bir bakış açısıyla metodolojik bir analiz yaparak, özellikle "düzen" kavramının bozulmasının ardından yaşanan süreçte, fenomenolojik bir bakışla afet anı ve sonrasını "paranteze alarak" tüm süreci mevcut sağduyu bilgisinden arınarak yeni baştan inşa edebilmenin gerekliliğini ve birey temelli anlam inşa süreçlerinin metodolojik açıdan incelenmesinin gerekliliğini tartışmaktadır.

\section{Sosyal Bilimlerde Afetlerin Tanımlanması}

Lindell'e göre, afetlerin, klasik, tehlike/ afet ve sosyal odaklı olmak üzere üç farklı kategoride tanımlama biçimi bulunmaktadır ve Fritz (1961:655), afeti, zaman ve mekâna bağlı biçimde gerçekleşen, toplumun ve toplum alt katmanlarının fiziksel zarar gördüğü, üyelerinin bir kısmının kayba uğradığı ve sosyal karışıklığa yol açan, sosyal yapının zarara uğradığı ve toplumun temel işlevlerini yerine getirmesinde kesinti yaratan olay olarak tanımlamaktadır (Lindell, 2013:797). Benzer biçimde Dynes'e göre afet ise, sosyal açıdan yıkıcı olan ve sosyolojik açıdan önem teşkil eden olay, vaka ve durumlar olarak tanımlanabilir (Dynes, 1988: 102). Türkçe literatürde yer alan ve Afetlere Sosyolojik açıdan yaklaşan ilk ve bütüncül derleme olan Afet Sosyolojisi adlı eserde, Can'ın afet tanımı da bu çalışma açısından önem taşımakta ve afetlerin sosyolojik boyutuna vurgu yapmaktadır;

\begin{abstract}
Afet, insan topluluklarının yaşadiğ yerlerde aniden veya zamanla oluşan, gerek doğanın gerekse de insanin doğrudan veya dolayl müdahalesiyle gerçekleșen; fiziksel, ekonomik, psikolojik ve daha birçok yönden büyük hasarlara ve kayıplara neden olan ve etkileri bakımından önemli sonuçlar doğuran sosyal bir olgudur (Can, 2020:20)
\end{abstract}

Afetlerin normal sosyal hayata zarar vermesi, kaos yaratabilmesi ve sosyal düzenin yeniden inşasına neden olması nedeniyle sosyal bir patoloji olarak görülebileceğini belirten Dynes(1978)'a karşı olarak, Fritz'in afetin sosyolojik tanımlaması afetlerin sosyal bir patoloji olarak görülemeyeceğine değinmektedir ve Fritz'e göre (1961); Afetler, bütünleşme, dayanıklılık ve sosyal sistemlerin iyileştirici gücünü test edebileceğimiz laboratuvarlardır. Afetler, sosyal bilimcilere insan davranışları çalışmalarında normal ve stabil koşullarda karşılaşılamayacak avantajlar sunar. Dolayısıyla, rutin olanın dışında gerçekleşen toplumsal etkileşimler ve toplumsal hareketler aynı zamanda sosyolojik açıdan her an karşılaşılmayan "olağan dışı”"nı anlayabilmek için önemli olanaklar sunmaktadır. Bu bağlamda, Şentürk de afetlerin sosyal değişmeye olan etkisini şu şekilde ortaya koymaktadır;

Afet sırasında ve sonrasında meydana gelen karışıklık durumları, kolektif eylemler yanı sira beliren ekonomik ve sosyal ihtiyaçları karşılayacak yeni yapılanmalar, değişimin merkezinde büyük rol oynamaktadır (Şentürk, 2020: 122). Özellikle, Türkiye'de 17 Ağustos 1999'da yaşanan en yıkıcı deprem sonrasinda devletin kurumsal yetersizlikleri ve müdahalelerdeki zaman kayıplarında, AKUT gibi sivil toplum oluşumlarının devletin olağan işleyişiyle yaygın organizasyon ve koordinasyon, süratli karar ve uygulama, yerinde insiyatif ve ataklık gerektiren bu çapta bir sorun karşısında yer yer devre kaldığı bir noktada kendini göstermiştir tanımlamasıyla sivil toplumun, afet sonrası toplumsal değişmeyle olan ilişkisini betimlemektedir (Şentürk, 2020: 122).

Afet konusunda gerçekleştirilen çalışmalarda temel olarak farklı disiplinler ve farklı yaklaşımların varlığının belirtilmesi önemlidir. Alexander'a göre, afet araştırmalarında altı temel yaklaşım bulunmaktadır; $\mathrm{Bu}$ yaklaşımlar; Antropolojik yaklaşım, Sosyolojik yaklaşım, Coğrafi Yaklaşım, Gelişme Çalışmaları, Teknik Yaklaşım ve Afet Tedavi Yaklaşımı olarak tanımlanır Alexander (1993), Barrows (1923) ve White (1945) coğrafi yaklaşımın öncüleri olarak mekan- zamansal bir vurguyla insanın çevreye ekolojik adaptasyonunu, tehlikelerin etkilerinin dağılımını, kırılganlık ve insanların doğal tehlikelere karşı tercihleri ve düzenlemelerini sosyal bilim teknikleriyle incelerler (Nasreen, 2004: 23).

Oliver-Smith (1979), Hansen ve Oliver-Smith (1982) çalışmalarının öncülüğünü yaptığı Antropolojik yaklaşımda, nüfusun sosyo-ekonomik değerlendirmesinde afetlerin rolü ve ayrıca örneğin Üçüncü Dünya Ülkelerinde afet ve dezavantajlı grupların hayatta kalma stratejilerine odaklanmaktadır. Dynes (1970), Quarantelli (1978), Milleti, Drabek ve Haas'ın (1975) ve Drabek'in (1986) çalışmalarının temeli oluşturduğu sosyolojik yaklaşım ise temelde kırılganlık ve afetlerin insan davranışları üzerindeki etkileri ve afetlerin toplumun ve örgütlenmelerin işleyişindeki etkileri üzerine odaklanmaktadır (Nasreen, 2004: 23). Sosyolojik yaklaşımın afetlerin fiziksel olduğu kadar toplumsal olarak da etkileri üzerine odaklanmasının ardında, temel olarak toplumun ve sıradan bireylerin olağan ve rutin olanın dışında kesintiye uğrayan bir akış içerisinde sergiledikleri toplumsal davranışların, toplumsal yap1 üzerinde önemli bir analiz unsuru olabileceği düşüncesi yatmaktadır. Antropolojik yaklaşımda ise Oliver-Smith üç temel nokta üzerine odaklanmaktadır ve davranışsal cevap yaklaşımı, sosyal değişme yaklaşımı ve politik/ekonomik çevre yaklaşımı olarak tanımladığı bu üç tema ekseninde Oliver-Smith'e göre (1979); gelişmekte olan ülkelerde afetler toplum, teknoloji ve çevre ortak yüzeyinde gerçekleşir ve kaçınılmaz olarak bu üç karakteristiğin etkileşim sonuçlarından etkilenir.

Gelişme çalışmaları yaklaşımında Davis (1978) ve Knott (1987) temelde üçüncü dünya ülkelerindeki yardımların dağıtımı, göçmen yönetimi, sağlık ve açlık ve yoksullukla mücadele bağlamındaki problemlere odaklanır (Nasreen, 2004: 23). Son olarak da teknik yaklaşımda jeofiziksel özelliklere odaklanan sismoloji, jeomorfoloji ve volkan bilimi, afet öncesi ve sonrasına ilişkin mühendislik temelli çözümler üretme çabasındadır.

$\mathrm{Bu}$ çalışmanın odaklandığı ve fiziksel bir olay olan afet çalışmalarında çalışılan ana başlıklar planlama, uyarı, tahliye, acil müdahale, tahliye, yeniden yapılanma üzerine odaklanırken, afet sosyolojisinde ana başlıklar hazırlıklı olmak, tepki, iyileşme ve zararı/hasarı iyileştirme üzerine yoğunlaşmaktadır (Drabek, 1986). Afetlerin Psiko-Sosyal Etkilerine odaklanan çalışmasında Bayhan, afet sonrasında meydana gelen travma sonrası stres bozukluğunun(TSSB) en yaygın incelenen bozukluk olduğunu ve bunu depresyon, anksiyete ve panik bozukluklarının izlediği ve ayrıca tüm felaketler sonrasinda ortak olarak tahmin ve kontrol 
eksikliği, kırılganlık, ölüm ve hayatlarının kontrolden çıktığını hissetmenin bireylerde belirsizliği arttırdığı ve bu durumun psiko-sosyal problemleri arttırdığını ortaya koymaktadır (Bayhan, 2020: 291).

Afet öncesi ve sonrasında belirleyici olan Afet Yönetimi Döngüsünde yer alan, hazırlık, müdahale, iyileştirme, önlem ve zarar azaltma boyutlarına değinen Akbaş ise, afet yönetiminde sosyal politikaların önemine vurgu yapmaktadır ve uygun sosyal politika tedbirleriyle doğal afetlerin etkilerini beşeri dokunuşlarla hafifletmenin mümkünlüğünü tartışmaktadır (Akbaş, 2020: 335). Akbaş’a göre, zarar azaltmaya dair toplumsal yaklaşımlar doğal afetler karşısında insanı edilgen olmaktan çıkarıp aktif bir özne konumuna yerleştirecektir. $\mathrm{Bu}$ noktada sadece toplumun afet bilincini artırmakla iktifa edilmemeli, aynı zamanda özellikle, engelli, çocuk, göçmen gibi incinebilir grupları güçlendirmeye yönelik tedbirler alınmasına yönelik dezavantajlı grupları güçlendirmek gereklidir (Akbaş, 2020: 335).

\subsection{Afet Sonrası Toplumsal Davranış}

Samuel Prince'ın 1925 y1lında Amerika'da Halifax Nova Scotia mühimmat gemisinde gerçekleşen patlamayı incelediği ve büyük felaketlerin ani bir sosyal değişme uyaranı yarattığını ortaya koyan çalışması literatürde yer alan ilk afet çalışması olma özelliğini taşımaktadır. Ayrıca; Afet Sosyolojisinde Sorokin'in "Man and Society in Calamity" adlı çalışması da öncü çalışmalar arasında yer almaktadır. Sorokin çalışmasında afet kavramı yerine musibet ya da bela kavramını kullanır ve doğal afetlerin yanına ilave ettiği devrim, savaşlar ya da salgın hastalıklarla beraber din, dezavantajlı gruplar, göç, kültürel hayati toplumsal yap1, afetlerin ekonomik etkilerine değinir ve bu anlamda çalışması afetlerin sosyolojik açıdan analizi bağlamında özgün ve öncül eserlerdendir. Afetlerin büyüklügüne ve etkilediği nüfusa göre farklı toplumsal değişme sonuçları yarattığını tartışan çalışmalara değinen Bates ve Peacok (1987), afetlerin toplumsal değişme sonucunu doğurmasında yedi temel nedeni ortaya koymaktadır;

1. Afetler sosyal sistemin yapisinı strese sokarak, mevcut işlevlerini yerine getirip getirmediğini kontrol eder. Dahası, sistem uyum sağlamaya zorlanır ve en azından geçici olarak bu strese ve bu strese neden olan koşullara uyum sağlamaya zorlanır ve bu geçici olan uyum süreci zaman içerisinde sosyal yapıda kalıcı değişimlere neden olabilir ya da ilişkili değişimler yaratabilir.

2. Afetler farkl sosyo-ekonomik ve etnik gruplar ve hatta toplumun farklı iş bölümü tabakalarını farkl biçimde etkiler ve sonuç olarak toplumsal tabakalaşma sistemi süreçten etkilenir ve sosyal yapının farklı kisımlarında farkl gerileme ya da ilerleme ortaya çıkabilir.

3. Afetler farklı grup ve örgütleri ortaya çıkarabilir ve yeni karşılaşmalar, işbirlikleri ya da mevcut gruplar ve örgütler arasında çatışma yaratabilir. Bu durum da bu örgütlenmelerin bir araya geldiklerinde sosyal yapıy oluşturan birimlerinde kalıcı değişimler yaratabilir.

4. Afetler sıklıkla eski ve modası geçen teknolojik altyapiya zarar verir ve bu altyapının yeni teknolojiyle değiştirilmesine zorlar. Bu teknolojik inovasyon da işbölümü ve tabakalaşma sisteminde farklilaşmalara yol açabilir.
5. Afetler genellikle işgücü ve uzmanlık sunan yabanct akışı ve aynı zamanda fiziki ve finansal diş kaynak oluşumuna olanak sağlar. Bu durum ekonomik patlama ve aynı zamanda iş gücü dağllımında ve tabakalarında farklılaşan büyüme yaratacak bir uyarım yaratır.

6. Yabancı olanlar beraberlerinde farklı davranış biçimleri ve afetten etkilenen toplumunkinden farkl yapisal örüntüler getirirler. Bu yeni davranış desenleri yerel nüfusa aktarlarak sistemin yapısında kalıcı bir değişim aracı olabilir.

7. Afetler sonrasında çoğunlukla, kıt kaynakların yeniden inşa sürecine yön verecek biçimde eşitlik ilkesiyle dağıtımı üzerine çatışmalar ortaya çıkmaktadır. Bu çatışmalar ciddi siyasi çıkarımlar oluşturabilir ve bu çatışmalar devlet ve diğer birimler arası ilişkileri kapsayan sistemde kalıcı değişim sonucunu doğurabilir. (Bates ve Peacok, $1987: 311-313)$.

Bates ve Peacok'un alıntısında afet sonrasında değișen toplumsal düzen ve yeniden inşa süreçleri ele alınmaktadır. Bireylerin fiziksel altyapı sorunlarına ve değişen düzene yeniden uyumu kimi zaman zorlayıcı olsa da, farklı iş bölümü alanları, tabakalaşma sistemlerinde ciddi değişiklikler, yeni örgütlenmeler, artan yabancı akışı, farklılaşan uzmanlık alanları, yabancılarla aktarılan farklı yapısal örüntüler gibi örneklerle toplumsal hayat ve birey açısından toplumsal ilişkiler yeniden kurulur ve yeni bir düzene doğru etkileşimler başlar. Dolayısıyla tüm bu kırılma ve yeniden inşa dönemleri insan ilişkileri ve toplumsal açıdan sosyolojik analize ihtiyaç duymaktadır.

Afet sonrasında toplumsal davranışları sosyolojik olarak tanımlayabilmeyi amaçlayan ve özellikle afet çalışmaları alanında öncü çalışmaların merkezi Amerika'da 1950 ve 1960'larda gerçekleştirilen ve temelde Soğuk Savaş Döneminde nükleer saldırıya karşı halkın nasıl tepki vereceği sorusuna yanıt arayan çalışmalar, afet sonrası toplumsal davranışa odaklanan ilk çalışmalar olma özelliğini taşımaktadır. Tierney vd.'nin aktardığına göre; Amerika'da, özellikle panik, kitlesel demoralizasyon ve sosyal kırılmanın grup davranışı üzerindeki etkileri incelendiğinde, tehlike altında grup üyelerinin ve afet kurbanlarının mevcut ani gelişen şartlara hemen uyum sağladığı ve gerekli müdahale konusunda panik içinde olmadan anında yanıt verdiği ortaya koyulmaktadır (Tierney vd. 2006: 58). 1960 yilında gerçekleştirilen afet çalışmalarına göre, toplumda afete maruz kalan bireyler, dışarıda yardım bekleyen afet kurbanlarına yardım edebilmek için proaktif bir biçimde hemen harekete geçmekte, arama, kurtarma faaliyetlerinde dikkat çekici bir toplumsallaşma örneği göstermekte ve toplumsal birliktelik en üst düzeye ulaşmaktadır. Ortaya konan bu üst düzey dayanışma ve birliktelik ve aktif yardım davranışları "vatandaşlık rollerinin genişlemesi ve sosyal ayarlama" olarak tanımlanmakta ve sapma davranışın en alt seviyede olduğu afet sonrası zamanlarda toplumsal davranış, toplumsal bütünleşmenin en üst seviyesinde gözlemlenmektedir (Fritz, 1961'den akt. Tierney, 2006). Özellikle afet mitleri olarak tanımlanan ve afet sonrası yağma ve sapma davranış üzerine gerçekleştirilen ilk çalışma olan Dynes ve Quarantinelli'nin "When Disaster Strikes (It Isn't Much Like What You Heard and Read About) 1972 yılında bir psikoloji makalesi olarak yayınlanmıştır. $\mathrm{Bu}$ çalışmada, özellikle medya ve film sektörü tarafından üretilen, afet sonrası her bireyin kendi yaşamsal gereklilikleri için toplumun diğer bireylerini feda edeceği ve 
hatta yok etmeyi göze alacağı iddiasına karşı toplumsal bütünleşme ve proaktif sosyal davranışların afet sonrası geliştiği iddia edilmektedir. Dolayısıyla, doğal afetler önceden öngörülmeyen bir biçimde, her ne kadar fiziki olarak yıkıma neden olsa da, toplumda bütünleştirici bir işlevi ortaya koyduğu afet sosyolojisine dair en önemli çıkarımlardan birini oluşturmaktadır.

$\mathrm{Bu}$ noktada afetlerin öngörülebilirliğiyle ilgili olarak altı çizilmesi gereken noktayı Alkın, Dünyada ve Türkiye'de Afet Sosyolojisi başlıklı çalışmasında tanımlamaktadır. Alkın, afet literatürünü derinlemesine incelediği çalışmasında doğal ve yapay afetleri farklı biçimlerde kavramsallaştırmaktadır. Bu kapsamda, depremler, seller, su baskınları, heyelanlar, volkanik patlamalar ve salgın hastalıklar gibi doğanın işleyişinden kaynaklı olan doğal afetler tanımlanırken, yapay afetler olarak insan temelli olan ve insanların çeşitli politik, ekonomik ya da teknolojik sebepler aracılığıyla yarattığı büyük çaplı zararları Turner'dan alıntıyla açıklar (Turner, 1978'den aktaran Alkın, 2020: 64). Yapay afetlere örnek olarak savaşlar, etnik çatışmalar, radyoaktif sızıntılar, plansız endüstrileşme sonucu su kaynaklarının kirletilmesi gibi durumları tanımlayan Alkın, ayrıca çağdaş afet sosyolojisinde gündeme gelmeye başlayan kasıtlı ve teknolojik afetleri de tartışarak, afetlerin aslında doğal olmaması yani yapay, kasıtlı ya da insan kaynaklı olması durumunda öngörülebilir ve önlenebilir olduğunu ortaya koymaktadır (Alkın, 2020: 64).

\section{Yöntem ve Uygulama}

Bu çalışma "afet” kavramının kuramsal açıdan incelenmesi, ilgili literatür üzerinden kavramın farklı boyutlarına değinen çalışmalara değinmek, literatür incelemeleri üzerinden Türkiye örneğine değinerek, Afet Sosyolojisi alanında yöntemsel bir model önerisinde bulunmayı amaçlamaktadır. $\mathrm{Bu}$ bağlamda araştırmada afet sosyolojisi literatüründe yer alan ve kuramın gelişmesine öncülük eden yaklaşımların analizi ve Türkiye afet yazını birlikte ele alınarak metodolojik bir inceleme yapılmıştır. Bir başka deyişle, Türkiye'deki afet çalışmalarına, sosyolojik ve metodolojik bir bakış geliştirilmeye çalışılmıştır.

\section{Afetlere Metodolojik Yaklașım}

Sosyolojik çalışmalarda, afetin kuraldışı/ istisna olarak, rutin olanın dışında olanı yani düzenin dışını anlamaya olanak vermesi önemli bir boyuttur. Dynes ve Drabek'in (1994) ve Fritz'in (1961) de belirttiği gibi, "Afet mevcut teorilere meydan okumak ve geliştirmek için eşsiz olanak sağlayan doğal bir laboratuvardır". Durkheim'in sapma ve suç gibi iki normal olmayan fenomenin, toplumların normal işleyiş ve özelliklerini olan tanımlamaya olanak sağlaması (Durkheim,1964:102-103), Garfinkel'in etnometodolojik tekniklerinde yer alan istisnanın rutini kavramak için sağladığı olanağı ortaya koyan sosyolojik açıklamalar, afetlerin sosyolojik olarak toplumu tanımlamaya sağladığı katkıyı ortaya koyarken rutine odaklanmaktadır;

"Prosedür olarak, benim tercihim tanıdık sahnelerle başlamak ve sorun çıkarmak için neler yapılacağını sormaktır. Dağınık/düzensiz bir etkileşim yaratmak için bir kimsenin ortaya koyacağl eylemler, bize gündelik hayatın olağan aktivitelerinin düzeni ve düzenli olarak nasıl üretilip korunduğunu anlatmalıdır" (Garfinkel'den akt. Stallings, 2002: 283).

Dolayısıyla afetlerin temel olarak, aniden gelişmesi ve çevreye beklenmedik ölçüde zarar vermesi ve yarattığı yıkım, toplumda mevcut toplumsal yapıların işleyişinde ve "düzenli" olanda beklenmedik değişimler yaratmaktadır. Öncelikle deprem, sel, çı̆̆ gibi herhangi bir afetin yaşam alanlarında yarattığı yıkım bireylerin fiziki yaşam alanlarını doğrudan yıktığı için, mekânsal olarak verilmesi gereken yaşamsal mücadele, afete maruz kalan toplumda topyekün bir yaşam ve kurtarma çabasına dönüşmektedir. Afetin hemen ardından zamana karşı verilen kurtarma ve hayatta kalabilme mücadelesinde, toplumsal dayanışmanın en üst düzeye çıkması, afet öncesi "rutin" içerisinde beklenenden daha üst düzeyde toplumsal etkileşimi ortaya koymaktadır.

Toplumsal etkileşim ve topyekûn sosyal dayanışma kavramlarıyla birlikte "afetzede" kavramı da afet sosyolojisi kapsamında önem kazanmaktadır ve afet çalışmalarında öne çıkarılması gerekli olan bir boyut olarak konuya dahil edilmektedir. Aydemir'in afete tanık olmayı, araştırmacının kendi deneyimleriyle aktarmanın sosyolojik mümkünlüğünü tartıştığı ve afetzede tiplemesi üzerine deneyimsel analizini sunduğu çalışmasında, afetler sonrasında yaşanan mağduriyeti tanımlamaktadır. Afetzede olmanın, kişilerin imkân ve kabiliyetleriyle önemli ölçüde tanımlandığını belirten Aydemir'e göre, kendi imkânlarıyla tedavi görebilen, yaralarını sarabilen, enkazını kaldırabilen insanlara karşın, yardım eli değmeden hiçbir şey yapamayan insanlar arasında afet öncesindeki sosyal eşitsizliğin tezahürleri benzer şekilde tekerrür edebilir (Aydemir, 2020: 316). Aydemir, kişisel deneyimler ve anlatılar üzerinden afetzede tiplemesi ortaya koymaktadır. Ayrıca Aydemir'e göre; olağanüstü bir olayın içine çekilme veya devam eden bir felakete maruz kalma, negatif duygularla sarmalanmış bir insanı ve mağduru üretir ve bu durum suçluluk, utanma, sinirlilik, kayg1, korku, güvensizlik, şüphe, öfke, suçlama, acı, üzüntü, yas, inanç yitimi, kızgınlık gibi insanı sarmalayan duyguları yaratır (Aydemir, 2020: 316-317). Çalışma bağlamında ise afetzedenin kişisel deneyimlerine odaklanmak etnometodolojik yöntemin ortaya konulabilmesi açısından önem taşımaktadır.

$\mathrm{Bu}$ çalışmada temel olarak amaçlanan, gündelik hayatın rutini içinde sorgulanmayan bir durumun dişında gerçekleşen bir anın sosyolojik olarak sorgulamasını yapabilmek ve afet sonrası ve özelde deprem sonrası yaşanan karmaşa içerisinde gerçekleşen toplumsal davranış süreçlerine fenomenolojik ve etnometodolojik yaklaşımla açıklama getirmeye çalışmaktır. Çalışmada bu iki yaklaşımının temel alınmasının nedeni, toplumsal hayatı anlamanın ipuçlarının gündelik olanda bulunması ve bireylerin "rutin" ve "sorgulanmayan" yaşam dünyalarında karşılarına çıkan düzensizliklerle baş ederken yeni toplumsal hayatın ve yeni düzenlerin kodlarını yeniden inşa etmeleridir. Fenomenolojinin yanı sıra etnometodolojik yaklaşım ile, fenomenolojik temel önermelerin toplumsal hayatın araştırılmasına yönelik geliştirilen bir yaklaşım daha eklenir.

Etnometodolojik yaklaşımın öncü isimlerinden Harold Garfinkel, sosyologların gündelik etkinliklerin istikrarlı özelliklerini incelerken genelde ev halkı veya işyeri gibi bilinen ortamları seçtiklerinden ve onların istikrarlı 
özelliklerine katkıda bulunan değişkenleri araştırdıklarını ortaya koyar ve ekler;

"Genelde belirli bir faktörler seti yani gündelik ortamların toplumsal olarak standartlaşmış ve standartlaşan "görülen ancak gözden kaçan", olması beklenen arka-plan özelliklerini sorgulamadan veri olarak alınır" (Garfinkel, 2014: 60-61).

Afet sosyolojisi tam da bu noktada görünenin ardına bakarak "görülen ancak gözden kaçan" birçok gerçekliğin arka planının incelenmesi ile, tamamen fiziksel yıkıma dayalı tartışmaların tek yönlülüğünden kurtulabilir. Afetlerin yalnızca doğa ile ilişkili olmasının yanına insan ve toplumsal davranışın eklenmesiyle birlikte Fenomenolojik sorgulama devreye girer ve mevcut tüm bilgi stoklarının alaşağı olduğu bir anda sıradan insan aslında hayatı "paranteze alır". Bunun nedeni o ana kadar tanıdık olan tüm bilgi stoklarının içermediği bir düzensizlik karşısında "bilineni askıya almaktır".

Gündelik hayatı anlamanın fenomenolojisini inşa eden Alfred Schutz, görülen ancak gözden kaçan birçok arka plan beklentiyi betimler ve arka plan beklentileri "gündelik hayat tutumu” olarak adlandırır; onların sahnelenen özelliklerini "genelde bilinen ve gerçekliği sorgulanmayan dünya" olarak niteler. Schutz'un temel çalışması arka-plan beklentilerin doğası ve işleyişini açıklamayı, onları müşterek eylemlerle bağlantılı süreçlerle ilişkilendirmeyi ve ampirik olarak tasavvur edilebilen bir toplum içindeki yerlerini değerlendirmeyi daha ileri düzeye taşımayı mümkün kılar (Garfinkel, 2014: 60).

Alfred Schutz "Yaşam dünyası" (Lebenswelt) kavramını Fenomenolojinin öncülerinden Edmund Husserl'den ödünç alır ve toplumsal hayat çözümlemesini öncelikle Yaşam Dünyasını anlamak çabası üzerine kurar. Burada Schutz pozitivist sosyolojik geleneğe karşı bir duruş sergileyerek, yapının belirleyiciliğinin yerine bireysel deneyimlerden türeyen algı ve bilinç üzerine odaklanır. Her bireyin farklı deneyimlerinden kaynaklı olarak farklı anlamlarla inşa ettiği yaşam dünyası içerisinde diğerlerinden edindiğimiz ve kimi zaman da öğrendiğimiz yorumlamalar belirleyicidir. Hem göreceli hem de yorumlamalara dayalı Yaşam Dünyası, bireylerin gündelik hayatlarının akışındaki bilişsel ve duygusal akışı sağduyuları ile yorumlanmakta ve kavranmaktadır. Gündelik hayat, sürekli yeniden inşa edilir ve bireyler arası anlam ve anlama dayalı etkileşimlerle yeniden inşa edilir ve tüm bireyler kendi anlamları ve eylemleriyle öğrenir ve her bireyin ilişkileri ve bu ilişkilerde yarattıkları anlamların toplamıla toplumsal hayat ve eylem tüm toplum tarafindan "sağduyu bilgisi" denilen biçimde kavranır ve bu eylemleri içeren bilgiler toplumun tüm bireyleri tarafindan bilgi stokları denilen bilgi paketleri olarak yapıp edilen tüm eylemlere yön verir (Schutz, 1973:67). Bilgi Stoklarını Schutz şu şekilde açıklar;

"Dil, dildeki çoğul tipleştirmeler, şeylerle baş edebilme ve onlarla ilişki kurabilme kurallarl, tüm ilişkiler, davranışlar ve belirli durumlardaki eylemler bir arada Bilgi Stoklarını oluşturur. Bu benim tüm yaşam hikayemin tortusudur ve otoritelerinin gücünü kabul ettiklerim ve bana ögretenler tarafindan aktarllan tüm öğretileri ve birliktelik ve arkadaşlık ilişkisi içinde olduklarımdan edindiğim her şeyi içermektedir. Dahası, bilgi stokum asla tamamlanmaz, tam tersine yaşantım devam ettikçe daha da genişler" (Schutz, 1970: xv111).

Bilgi stoklarının sadece küçük bir kısmının bireysel deneyimlerden ve daha büyük bir kısmının sosyalleşme yoluyla aktarıldığının ve bunların da birey tarafından kabul edildiğinin vurgusunu yapan Schutz, Sağduyu bilgisini de bilgi stoklarıyla ilişkili olarak tüm bu ortak bilgi stokları aracılığıyla toplumsal hayatımızda nasıl davranacağımızın nasıl yorumlamalarda bulunacağımızın anahtarı olarak tanımlar (Schutz, 1970, 5).

Bu çalışmayla ilişkili olarak afetler gibi alışageldik olmayan zaman dilimlerinde, alışılmadık durumlara yönelik eylemlerin inşası fenomenolojinin önemli önermelerinden olan "paranteze almak" durumu ile açılanabilir. Fenomenolojik yaklaşımın öncülerinden Husserl bu durumu şöyle açıklar;

"Gündelik hayatımızda, doğal durumda, dünyayı ve gerçekleri sorgulamadan bir şekilde bir yerde var olduklarl şekliyle kabul ederiz... Radikal bir çabayla, dış dünyaya dair saf inancımızı inançsızlıkla değiştirmeden, sadece inancımızı düşüncemizi askıya alarak bu durumu değiştirebiliriz. Sadece mekânzamansal varoluşumuzla ilişkili herhangi bir yargıdan uzak durarak, ya da teknik bir dille, dünyanın var oluşunu "kullanım dişı" birakıp, ona dair inancımızı paranteze alırız. Bu belirli tekniği kullanarak, yalnızca gündelik hayatımıza dair să̆duyusal yargıları asklya almakla kalmaz aynı zamanda, doğal tutumda bu dünyanın gerçeklikleriyle ilişkili doğa bilimlerinin tüm önermelerini de paranteze alırız" (Schutz, 1970: 5).

Paranteze almak, alıntıda belirtildiği gibi sorgulanmayan ve düzen içinde devam eden yaşam dünyasında, bireyin o zaman kadar tüm etkileşim ve sosyalleşme süreçleri çerçevesinde edindiği sağduyu bilgisini yani aslında bilinen her şeyi askıya almaktır. Fenomenolojinin bu tekniği ile hiçbir şey bilmeden ya da herhangi bir şeye inanmadan ve hatta doğa bilimlerinin pozitivist tüm iddialarını da bir kenara atarak, o anın bilgisini ya da inancını yeniden bireyin ya da araştırmacının kendi başına kurmasıdır. Geride kalan tüm birikimlerin yanına o "anda" olmanın biricik ve özgül bilgisini üretebilmeyi başarmak, fenomenolojik indirgeme ya da paranteze almanın gerçekleşebilmesi anlamını taşımaktadır. Afeti yaşayan bireyler de aynı şekilde, "İlk defa karşılaştıkları durumlar karşısında bilgi stokundaki bilgilerden yardım alamayan birey, askıya aldığı şüphelerini yeniden değerlendirir ve bunları ortadan kaldıracak yeni çözümler arar” (Sofuoğlu Kılıç: 2012: 140).

Fenomenolojinin ilkelerinin toplumsal araştırmalarda ve özellikle saha çalışmalarında kullanılmasıyla şekillenen bir kuram olarak etnometodoloji, kökleri fenomenolojide olan, insanların sıradan gündelik hayatta kullandıkları bazı yöntemlerle toplumsal düzeni ürettikleri varsayımına dayanan ve bu yöntemleri inceleyerek hem gündelik hayatın ilk anda görünmeyen kurallarını hem de insanların toplumsal düzeni nasıl anlamlandırıp ürettiklerini ortaya koymaya çalışan yaklaşımdır. Bu kuramın temel amacının insanların gündelik yaşantılarını gerçekleştirdikleri ve farklı ilişkileri sürdürürken kullandıkları metotlar veya prosedürleri analiz etmek ve insanların sosyal gerçeklik duygusunu nasıl yarattıklarını, sürdürdüklerini ve değiştirdiklerini 
açıklamaya yardımcı olabilecek kavramlar ve ilkeler geliştirmeye çalışmak olduğu söylenebilir (Çetin, 2017:9495).

Bireyler üzerinden yaşamlarının bu yeni deneyiminin bilgisini üretmeye yönelik çaba ile etnometodolojik yöntem devreye girer ve etnometodolojinin amacina uygun olarak, insanların toplumsal dünyayı anlamlandırmak için kullandıkları yöntemleri inceleyerek afet ve sonrasının görünmeyen yanlarını ortaya koymayı hedefler. Bu durumda bireylerin daha önce başkalarının tanımladıklarının aksine kendilerinin bu "afet" durumunu nasıl tanımladıkları, anlamlandırdıkları ve ortak bir tanımı nasıl birlikte inşa ettiklerini açıklamak mümkün olabilir. $\mathrm{Bu}$ bağlamda etnometodolojinin sosyal bilimlere kazandırdığı bir kavram olan bağlama-gönderimlilik önem kazanır ve afet sonrası ortamda o bağlama ilişkin özel anlamların tanımlanmasında anlam kazanır.

\section{Bağlama- gönderimlilik bir sözcüğe yüklenen bütün bağlamsal hükümlerdir ve dil bilimcilerden uyarlanan teknik bir terimdir ve bu kavrama göre bir sözcük, bir durumdan bă̆ımsız bir anlama sahip olsa bile, kullandı̆̆ her özel durumda ayr bir anlam kazanır... Sözcükler kesin anlamlarını sadece üretildikleri somut bağlamlarda dilsel bir alışveriş durumunda "bağlama gönderim yaparken" kazanırlar. Sözcüklerin, bağlamdan bă̆ımsız her zaman geçerli olan değişmez anlamları yoktur. Yani kelimelerin anlamlart nesnel değildir. Insanlar, kelimeleri, konuşanın kim olduğuna, konuşan ve dinleyen arasındaki ilişkinin ne olduğuna, konuşmanın amacının ne olduğuna bakarak anlamlandırır (Çetin, 2017: 98).}

Bağlama gönderimliliğin "sözcüklerin bağlamdan bă̆ımsız her zaman geçerli olan anlamlarl yoktur" önermesi afet çalışmalarında değerlendirilen temel kavramların, bireyler arası anlamların, afet anının gerçekleşmesinin hemen ardından ve kendi bağlamı içinde ele alınmasının fenomenolojik ve etnometodolojik kuramlar bağlamında önemini ortaya koymaktadır. Dolayısıyla afet sonrasında "bireyi", "toplumu" ya da herhangi bir ilișki biçimini metodolojik yöntemlerle incelemek, hem birey, hem de sıradan olan gündelik hayat kurgusunun ve düzenin değişime uğramasının analitik ve sosyolojik incelenmesi açısından araştırmaları daha güçlü kılacaktır. Bireylerin değişen düzenlerinin yeniden inşasına yükledikleri anlamları bağlamından uzak olmadan, bireylerin kendi anlam ve ifadelerini dikkate alarak ve afetlerin "şimdiliğì" ekseninde incelemek mevcut sosyal bilim afet yazınının sosyolojik yanına güç katacaktır.

\section{Türkiye'de Afet Çalışmaları}

Afet kavramının sıklıkla depremle birebir ilişkilendirildiği bir coğrafya olarak Türkiye'de afet yönetimiyle ilgili kurumsal çalışmalar Afet ve Acil Durum Yönetimi Başkanlığı (AFAD) tarafından yürütülmektedir. AFAD tarafından tanımlanan 31 çeşit afet bulunmaktadır ve bu sayının 28 tanesi meteorolojik ve doğa olaylarıyla ilişkili afetlerdir. AFAD verilerine göre Türkiye'de en sık rastlanılan afetler doğal afetler olarak tanımlanabilecek meteorolojik karakterli afetlerdir ve orman yangınları, sel, taşkın, don, dolu, kuraklık, şiddetli yağış, şiddetli rüzgar, firtına, yıldırım ve kar firtınaları olarak sıralanabilir ${ }^{1}$. Ayrıca bu doğal afetler yavaş gelişen doğal afetler (şiddetli soğuklar, kıtlık, kuraklık) ve ani gelişen doğal afetler (deprem, selleri su taşkınları, toprak kaymaları, çı̆̆ fırtına, hortum, volkan patlamaları ve yangınlar) olarak ve jeolojik (deprem, heyelan, volkanik patlamalar, tsunami çamur akıntıları), klimatik (sıcak ve soğuk dalgası, kuraklık, dolu, hortum, yıldırım, kasırga) biyolojik (erozyon, orman yangınları, salgınlar ve böcek istilaları) sosyal (yangınlar, savaşlar, terör saldırıları ve göçler) ve teknolojik afetler (maden kazaları, biyolojik, nükleer, kimyasal silahlar ve kazalar, sanayi kazaları ve ulaşım kazaları) olarak bilimsel açıdan kategorize edilmektedir ${ }^{2}$

Türkiye'de afet ve afet yönetimi sıklıkla depremlerle ilişkili ve afet kavramı depremle eş değer bir kavrayışla ele alınmaktadır, ancak Türkiye'de depremlerden sonra su baskınları, erozyon, çığ düşmesi, kaya düşmesi gibi doğal afetler de siklikla meydana gelmektedir. $\mathrm{Bu}$ nedenle Türkiye'de afetlerle ilgili yapılan çalışmalar da temel olarak Deprem Sosyolojisi ve özellikle en büyük fiziki ve insani kaybı doğuran 17 Ağustos 1999 İzmit Körfezi (Marmara) Depremine odaklanmaktadır. Resmi kayıtlara göre 17.480 kişinin hayatını kaybettiği 1999 Marmara Depremi ve aynı y1l içerisinde meydana gelen ve yine resmi rakamlara göre 763 kişinin hayatını kaybettiği 12 Kasım 1999 Düzce depremi, 32968 kişinin yaşamını yitirdiği 27 Aralık 1939 Erzincan Depremi, 19 Ağustos 1966 Muş (Varto) Depremi, 2396 kişi, 24 Kasım 1976 Muradiye Van Depremi, 3840 kişi, 23 Ekim 2011 Van Depremi 644 kişinin yaşamını yitirdiği en büyük depremler olarak kayıtlara girmiştir.

17 Ağustos Marmara depremi, 17.480 kişinin yaşamını yitirmesinin yanında 43.953 kişinin yaralanması, 675.000 kişinin evsiz kalması, 15 milyonluk nüfusun depremden etkilenmesi ve 13 milyon dolarlık tahmini ekonomik zarar ile Türkiye'nin en önemli doğal afeti olarak kabul edilebilir (Ergünay,2007:2). Bu nedenle Türkiye'de Afet sosyolojisi çalışmalarına 1999 Marmara Depremi sonrasında yoğunlaşılmaktadır ve çalışmalarda temel olarak 1999 Marmara Depremi sonrasında yaşanan toplumsal travmanın psikolojik boyutları, devletin ve sivil toplumun müdahale konusunda müdahale kapasiteleri üzerine eleştiriler dikkat çekmektedir. Temel olarak, 1999 Marmara Depreminin yarattığı ciddi insan kaybı ve beraberinde gerçekleşen fiziki yıkım sonucunda, Deprem ve toplum ilişkisi, sosyolojik araştırmalarda daha fazla konu edilmeye başlanmıştır. Marmara Depremi sonrasında, depreme hazırlık konusunda multidisipliner araştırmaların önemi vurgulanmış ve afetlere dair toplumsal anlamda farkındalık yaratmak ve hazırlık süreçlerinin hızlandırılması gibi temel konular çalışmalarda yer almaya başlamıştır. Ecevit ve Kasapoğlu, Depremin Sosyolojik Analizini yaparken temel olarak, depreme hazırlıklı olmak için depremle ilgilenen tüm disiplinlerin sosyologlarla birlikte çalışması gerektiği vurgulanmış ve afetzedelerin eğitim durumu, yabancılaşma, endişeler ve geleneksellik kavramları üzerine bulgular elde edilmiştir (Kasapoğlu ve Ecevit, 2001'den akt. Bilik, 2015: 2). 1999 yılı içerisinde Marmara Depremi'nden hemen sonra yine oldukça önemli can ve mal kaybına neden olan 12 Kasım Düzce Depremi de, sosyal bilimler ve özellikle sosyolojik açıdan depremlere artan akademik ilgiyi doğurmuştur. 
"Depremden Beş Yll Sonra Düzce" araştırması deprem sonrası Düzce'de Marmara Üniversitesi Sosyoloji Bölümü öğretim üyelerince gerçekleştirilmiş ve proje raporunda belirtildiği üzere, dört ana kapsam üzerine yoğunlaşmaktadır. Öncelikle deprem deneyimi ve beraberinde psiko-sosyal sorunlar, kişisel yaşamlarda ve rollerde ortaya çıkan değişimler, ekonomik yaşamdaki değişim ve sorunlar ve sivil toplum kuruluşlarının bölgedeki gelişimi ve işlevidir (Kümbetoğlu vd. 2007).

Türkiye'de meydana gelen depremler ve sonrasında yaşanan devlet- sivil toplum işbirliği ve kimi zaman da çatışmasının yanında, deprem sonrası yeniden inşa ve toparlanma süreçleri bağlamında sosyolojik açıdan ele alınmaktadır. Bütün bu sosyolojik bağlamlar, afet konusunda Türkiye'de sosyal bilimler literatürü ve özel olarak sosyolojinin deprem sosyolojisi üzerine odaklandığını ortaya koymaktadır. Dolayısıyla, bu çalışma, afet ve depremlerin tek tip olarak ele alınarak indirgemeci bir biçimde incelenmesi ve bunu da Türkiye'nin geçirdiği büyük depremler sonrasına odaklanarak analiz edebilme çabasının, Türkiye'de sosyoloji çalışmalarının, uluslararası afet sosyolojisi alanından uzak kalmasına ve bu alanda çalışmalar üretilmemesine neden olduğunu iddia etmektedir.

Özel olarak deprem üzerine odaklanan ve literatürde en fazla atıflanan çalışma olan ve Kasapoğlu ve Ecevit tarafindan 1999 Doğu Marmara Depreminin Sosyolojik Araştırmasını ortaya koyan çalışma alanda öncü çalışmalardandır. Kasapoğlu ve Ecevit, depremin sosyolojik boyutunu ortaya koyarken toplumsal düzen ve çatışma dikotomisinden hareket etmekte ve rutin ve alışılagelenin dışına çıkmanın getirdiği belirsizlik döneminin incelemesine sosyolojik bakış getirmektedir;

Toplumlar hızla değişmelerine ve sürekli yeniden inşa olmalarına rağmen belirli bir yapıya da sahiptir. Düzen, değişme ve çatışma bu yüzden sosyolojinin temel kavramlarıdır. Isşte deprem gibi doğal olaylar, toplumdaki mevcut düzeni sarstığından sosyolojik olarak önem kazanmaktadirlar. Deprem nedeniyle insanlarn gerçekleştirdikleri ve alışageldikleri yaşamları alt üst olmuştur...Mevcut sosyal düzenin ylkılması ve sosyal çözülmelerin yaygınlaşması toplumda yeniden düzenlenme ihtiyacını doğurmuştur. Gelişmekte olan ülkelerde bu türden bir yaplanma zordur ve toplumun buna yönelik hazırlıkları gelişmiş düzeyde değildir. Çoğu afetzede için geçici olmaktan ziyade kalıcı bir biçimde kurmuş oldukları sosyal düzenleri sarsılmıs,, gelecek hakkındaki belirsizlikleri yoğunlaşmış, geniş anlamda "yabancılaşma" ve "güç çatışmaları" yaşanmaya başlamıştır (Kasapoğlu ve Ecevit, 2001: 9).

Alıntıda afetler ve özelde depremlerin bireylerin alışılagelen ve rutinleşen hayatlarındaki gündelik etkinliklerin kesintiye uğramasının toplumsal öneminin altı çizilmektedir. Olağan olan akışın normal kabul edilip, sorgulanmaması ve ardından bir afet ile gelen kesintinin yarattığı düzendeki bozulma ise afetlere sosyolojik bakışın temelini oluşturmaktadır. Afet çalışmalarının sosyolojik boyutunda, düzen kavramı klasik sosyolojiden beslenen biçimde denge ile yakın ilişkili olarak kavramsallaştırılmakta ve özellikle depremler sonrası oluşan karmaşa ortamının toplumsal hayata düzensizlik noktasında etkileri araştırma konusu edilmektedir. Ancak, konunun bu boyutunda özellikle Türkiye'de afet sosyolojisinin gelişme yetersiz kaldığ 1 iddia edilebilir. Bunun nedeni, afet kavramının birebir depremle eş anlamlı kabul edilerek, deprem sonrası çalışmalara odaklanılması ve depremin sosyolojik boyutundan ziyade, deprem sonrası yaşanan sorunlar, afete hazırlık ve afet yönetimi konuları ele alınmaktadır.

Bu çalışmanın yayına hazırlandığı 2020 yılı itibariyle, İslam Can'ın editörlüğünde yayınlanan Afet Sosyolojisi çalışması, afet yazınında en güncel sosyolojik analizi içeren kaynak olarak literatürde yerini almıştır. Derleme eserde, bu çalışmanın da temel sorunsallarını oluşturan, afetlere sosyolojik açıdan bakabilmenin farklı boyutları ele alınmış ve on altı farklı bölümde afet kavramsallaştırması, türleri, afet sosyolojisine metodolojik bakış, afet- toplum ilişkisi, afet ve toplumsal değişme, afet türlerinin sosyolojik çözümlenmesi, bir afet türü olarak salgınlar, afetlerin ekonomik, psiko-sosyal etkileri, afet-din ve toplum ilişkisi, afetlerde dezavantajlı gruplar, afet ve sosyal politikalar, kriz yönetimi ve afetzede olmanın deneyimleri gibi başlıklarla, afetin farklı boyutları analiz edilmiş ve alanda önemli eksikliğe, en güncel gelişmeler ekseninde katkı sağlanmıştır.

Deprem konusunda mevcut çalışmaların metodolojik açıdan incelemesini yaparak, Türkiye'de Sosyal Boyutlu Deprem Çalışmalarını analiz eden Açıkalın, ele aldığı 139 makalede, deprem çalışmalarında tek boyutlu çalışmaların egemen olduğunu belirtirken, çalışmasının sonuç bulgusu olarak; farklı mekân ve zamanlarda ama aynı deprem sonrası dönemde, aynı konu/tema ve aynı toplum kesimi (veya aynı dönem-yer-konu ama farklı gruplar) üzerine aynı tür veri toplanıp analiz edilmediğini ve bir deprem bölgesinde farklı dönemlerde aynı grup ve aynı katılımcılar da çalışılmadığını ortaya koymakta ve böylece 2017 itibariyle, depremin sosyal boyutlarını etraflıca anlayabileceğimiz bir Türkiye temsiline ulaşamamışız" iddiasında bulunmaktadır (Açıkalın, 2018:99). Bu iddiayı destekleyen incelemesinde Açıkalın,

"Neden ve nasıl oluyor da hâlâ depreme dayanıklı bir toplum haline gelemedik?" sorusuna cevap verebilecek kavramlar ve kuramlar geliştirememişiz. Bunların yerine ortaya kabaca şöyle bir betimleme çıkarmışı: Depremden sonra bireyler dert çekmişler; toplum büyük bir dayanışma göstermiş; bireylere göre devlet onlara yeterince yardım etmemiş, fakat devlete göre olabilecek her olanak fazlasiyla verilmiş; en sonunda (ama aslında kusa sürede) herkes deprem hiç olmamış ve artık hiç olmayacakmış gibi davranmaya başlamış” (Açıkalın, 2018:99) . Açıkalın'ın araştırma bulgusu olarak ortaya koyduğu, bireylerin deprem sonrası dertlerine devletin yardım sağlama, muhtaçlık ve yoksunluk ve devletin yeterliliği tartışma ve araştırma çıktılarının deprem çalışmalarında egemen olduğunu vurgulamaktadır. Devlet- toplum ihtiyaç karşılama ikiliği içerisinde de, temelde teorik yaklaşımlar arka plana atılarak ve hatta kimi zaman hiçbir teorik tartışma inşa etmeden, deprem sonrası sorun tespiti ve öneriler sunulması noktalarına odaklanılmıştır. Dahası Açıkalın'ın incelediği deprem yazınına ilişkin makaleler ve çalışmaların temel olarak bir krizin ortaya çıkmasından sonra mevcut toplumsal dikkatin yoğunlaştığg alanlardan veri üretme kaygılarını yansıttığı belirtilirken, tek bir zaman boyutunda ve yalnızca afete maruz kalan topluluklar üzerinde gerçekleştirilen araştırmaların, deprem ve özellikle afet sosyolojisi yazınına teorik katkıları son derece kısıtlı görülmektedir (Açıkalın, 2018: 85).

Açıkalın tarafından analiz edilen Türkiye'de depremin sosyal boyutuna ilişkin yazında, araştırmaların \% 39'unun 
Marmara depremini takip eden ilk beş yılda yapıldı̆̆ 1 , araştırmaların \% 60’’nın Marmara Bölgesi, \% 34’ünün ise bir diğer önemli deprem bölgesi olan Van üzerine yoğunlaştığı, araştırmaların \%24'ünde temel atıf verilen yazarlar Kasapoğlu ve Ecevit iken \% 20'sinde Psikolog Karancı'nın deprem ve deprem hasarlarını azaltma, depreme hazırlama temelinde hazırlanan çalışmaları olduğu ortaya konulmaktadır (Açıkalın, 2018: 92-93-97)

Kasapoğlu ve Ecevit'in Türkiye'de Deprem sosyolojisinde en önemli yer tutan ve yukarıda belirtildiği gibi en çok atıf alan çalışması "Depremin Sosyolojik Araştırması"'nda yer alan ve Türkiye'deki deprem çalışmalarını yine bir literatür taraması şeklinde sundukları ilgili bölümde, Barka 1988, Erdik 1999, Ergünay 1999 gibi isimlerin çalışmaları yer bilimleri alanındaki çalışmalar olarak ortaya konulmaları ve depremi sonuçları sosyal olan bir doğa olayı olarak değerlendirirken, bir diğer önemli deprem çalışması ise Psikolog Karancı ve arkadaşlarının 1999 yılında gerçekleştirdikleri ve özellikle deprem hasarlarını azaltma, depreme hazırlama ve güçlerini kaybetmiş insanların topluma katılımlarını yükseltme mekanizmalarının yaratılması konularına değinmektedir (Kasapoğlu ve Ecevit, 2001: 12) . Kasapoğlu ve Ecevit ise alanın öncü çalışmalarından kabul edilen çalışmalarının amaçlarını şu şekilde özetlemektedir;

a) Deprem Bölgesinde prefabrik evlerde barınan insanların yaşamlarında, gerek sosyo-ekonomik yapısal unsurlar ve gerekse sosyal ve psikolojik temeldeki değer ve tutumlar açısından ne tür değişmeler olmuştur?

b) Bundan sonraki olası depremlere karşı hazırlıkl olmak üzere sorumlu/duyarl davranışta bulunma durumu ile bu tür davranışta bulunmayı etkileyen faktörler nelerdir?

c) Bu çerçevede, gelecekteki depremlerin oluşturacağ toplumsal hasarlarin asgariyel kabul edilebilir düzeylere indirilmesine yönelik temel öneriler neler olabilir? ( Kasapoğlu ve Ecevit, 2001: 18)

Dolayısıyla, deprem ve afet yazınına ilişkin bu literatür analizini içeren çalışma da, bu çalışmanın temel sorunsalı olan, afetlerin sosyolojik arka planına bakabilmek ve bunu rutinlerin yıkılması ve özellikle fenomenolojik ve etnometodolojik bir zemine oturtabilme çabasının gerekliliğini destekler niteliktedir. Bilinen tüm afet durumlarına ilişkin, tanımlar, durumlar, öncesi ve sonrasında özellikle devlet ve vatandaş arasında ihtiyaçların karşılanması noktasındaki yeterlilik ve yetersizlikleri analiz etme temelinde inşa edilen afet çalışmalarını sosyolojik bir paranteze alarak incelemek bu çalışmada vurgulanan gerekliliklerden biridir.

\section{Sonuc}

Bu çalışma, Fritz'in (1961) "“afetlerin sosyal bir patoloji olarak görülemeyeceğine dair iddiasından hareketle ve afetlerin, bütünleşme, dayanıklılık ve sosyal sistemlerin iyileştirici gücünü test edebileceğimiz laboratuvarlardır" önermesiyle yola çıkmıştır. Fiziksel bir yıkımın beraberinde getirdiği insani kayıplar, alt yapı sorunları, yeniden inşa süreçleri ve afetlere hazırlık alanlarında mevcut yazının koruma ve ders çıkarma niteliklerine karşıt olarak, afetlerin, sosyal bilimcilere insan davranışları çalışmalarında normal ve stabil koşullarda karşılaşılamayacak avantajlar sunacağ düşünülmektedir. Her bir bireyin kendi yaşam dünyasında deneyimlediği "afet" anı ve sonrasının hem toplumsal düzenin yeniden inşası hem de bireylerin anlam dünyalarında yarattı̆̆ı değişim, afetlerin yalnızca temel bilimlerin sorunu olmaktan uzak olduğunu ortaya koymaktadır.

Özellikle deprem odaklı kurgulanan afet çalışmalarının yalnızca tek bir alanda değil, toplumu olumsuz etkileyen ve afet olarak tanımlanan her türlü olumsuz koşulda daha da odaklanarak, sosyolojik metodolojinin daha yaygın kullanılmasını hedeflemek afet sosyolojisi alanına katkı sunacaktır. Afetlerin yalnızca yıkım ve tahribat ekseninde değil, aynı zamanda toplumsal hayatın ve bireyin gündelik ve toplumsal hayatında geçirdiği değişimler ve yeniden kurgulanan toplumsal hayat ekseninde analiz edilmesi, bireyin varlığının afet çalışmalarına sosyolojik olarak kabulünü mümkün kılacaktır. Kriz dönemlerinde gündelik hayatın kesintiye uğraması, rutinin bozularak kaotik ortamların ortaya çıkması gündelik olanın da yıkılıp yeniden inşasını gündeme getirdiğinden dolayı, fenomenolojik ve etnometodolojik sorgulamalar afet sonrası araştırmalarda birey ve toplum resmini daha detaylı görebilmek açısından yeni açılımlar sunacaktır. Bu bağlamda, mevcut tüm bilgi stoklarını paranteze alarak, kimi zaman mevcut afet yazınının egemen söylemlerine de karşı çıkarak, bireye ve yaşam dünyalarına odaklanmak gereklidir. Bunun yanı sıra, paranteze alınan "afet" sonrası yaşam dünyasında, bağlamagönderimlilik ilkesiyle, bireylerin "afet", "yaşam", "birliktelik", "toplumsal ilişki", "dayanışma" ve hatta "ölüm" gibi kavramları nasıl tanımladıkları "afet" bağlamında ele alınmalı ve etnometodolojik yöntemle büyük makro ve yapısal araştırmalar yer değiştirmelidir.

Türkiye'nin coğrafi koşulları dikkate alındığında yaşanması muhtemel sel, hortum, çığ düşmesi gibi diğer afetlerde de esas olarak, sosyolojik bağlamda yalnızca devlet- vatandaş ilişkisi ekseninde değil, gerçekleştirilen pro aktif dayanışma süreçleri, farklılaşan örgütlenmeler, tabakalaşma ile ilgili değişimler ile yeniden inşa edilen yeni rutinin bilgisine metodolojik temelli çalışmalar ekseninde ulaşabilmek gereklidir.

Türkiye özelinde yalnızca deprem ve sonrasında yaşanan kaos değil aynı zamanda bireylerin anlam ve toplumsal ilişkilerini de yeniden kurguladıkları önemli bir sosyal yaşam deneyimi olarak kabul edilmelidir. Sosyal destek ve dayanışmanın toplumsal öneminin ön plana çıkmasının yanında, toplumsal eylem tiplerinin de rutin dışında nasıl değişip dönüştüğünün incelenmesi de sosyolojik yönteme önemli katkılar sunacaktır. Bu bağlamda, afet öncesi ve sonrası hazırlık temelli yaklaşımların yanına birey temelli mikro analizler ve bireyin gündelik ve toplumsal hayatının yeniden inşasına odaklanan sosyolojik yaklaşımlar eklenmelidir. Etnometodolojik yaklaşımın bağlama gönderimlilik ilkesi ekseninde, “an” ve "bağlam”1n ön plana alınarak, "hangi anlam, hangi ilişki ve hangi tanımlama hangi sosyolojik yapılanma ve etkileşime" göndermede bulunuyor bunun tespit edilmesinin, mevcut afet yazınını sosyolojik açıdan daha da geliştireceği düşünülmektedir. 


\section{Kaynakça}

Açıkalın, O. (2018). Türkiye'ye İlişkin Sosyal Boyutlu Deprem Yazınına Eleştirel Bir Bakış Resilience (Dirençlilik) Dergisi Cilt: 2 Sayı: 2, 85-104.

Akbaş, E. (2020). Afetler ve Sosyal Politika. İ. Can (Ed.), Afet Sosyolojisi içinde (ss. 331-346), İstanbul: Çizgi Kitabevi.

Alkın, R. C. (2020). Dünyada ve Türkiye'de Afet Sosyolojisi, Afetlerin Sosyolojideki Yerine İlişkin Literatür Taraması, İ. Can (Ed.), Afet Sosyolojisi içinde (ss.63-81), İstanbul: Çizgi Kitabevi.

Aydemir, M. A. (2020). Afetlerde Ortaya Çıkan Kültürel Durum ve İnsan Halleri, Afetzede Tiplemesi Üzerine Deneyimsel Bir Analiz. İ. Can (Ed.), Afet Sosyolojisi içinde (ss. 305-326), İstanbul: Çizgi Kitabevi.

Bates, F.L. and W.G. Peacock. (1987). Disasters and Social Change. Pp. 291-330 in The Sociology of Disasters. Edited by R.R. Dynes, B. De Marchi, and C. Pelanda. Milan, İtalya: Franco Angeli Press.

Bayhan, V. (2020). Afetlerin Psiko-Sosyal Etkileri ve PsikoSosyal Destek Uygulamaları, İ. Can (Ed.), Afet Sosyolojisi içinde (ss. 285-300), İstanbul: Çizgi Kitabevi.

Bilik, B. (2015). 2011 Van Depremi üzerine sosyolojik bir analiz -Mekan, Afet yönetimi, Algı- (Yayınlanmamış Yüksek Lisans Tezi). Yüzüncü Yll Üniversitesi, Sosyal Bilimler Enstitüsü. Van.

Can, İ. (Ed.). (2020). Afet Sosyolojisi, , İstanbul: Çizgi Kitabevi

Can, İ. (2020). Giriş Niyetine: Afet Sosyolojisine Alan Açma Çabası, İ. Can (Ed.), Afet Sosyolojisi içinde (ss. 1536), İstanbul: Çizgi Kitabevi.Çetin, E. (2017). Gündelik Hayata Sosyolojik Bakmak, Ankara: Siyasal Kitap.

Dynes, R. (1988). Cross- Cultural International Research: Sociology and Disaster, International Journal of Mass Emergencies and Disasters, August 1988, Vol.6, No.2; pp. 101-129.

Drabek, T. (1986). Human System Response to Disaster: An Inventory of Sociological Findings, London: Springer- Verlag.

Drabek, T. (2017). Sociology of Disaster. In K. Korgen (Ed.), The Cambridge Handbook of Sociology: Specialty and Interdisciplinary Studies (pp. 139147). Cambridge: Cambridge University Press. doi:10.1017/9781316418369.015

Durkheim, E. (1964). The Division of Labor in Society, Free Press of Glancoe.

Ergünay, O. (2007). Türkiye'nin Afet Profili, TMMOB Afet Seтровуити Bildiri Kitabl, 5-7 Aralık 2007, Ankara.

Fritz CE (1961) Disaster. In: Merton RK and Nisbet RA (eds) Contemporary Social Problems. New York: Harcourt, Brace and World, 651-694.
Garfinkel, H. (2014). Etnometodolojide Araştırmalar, Ankara: Heretik Yayınları.

Kasapoğlu, A.\& Ecevit, M. (2001), Depremin Sosyolojik Araştırması: Hasarları Azaltma ve Toplumu Depreme Hazırlikll Kllma, Ankara: Sosyoloji Derneği Yayınları.

Schutz, A. (1970). The Collected Papers III, Studies in Phenomenological Philosophy, Ed. I. Schutz, Martinus Nijhoff, The Hague, Hollanda.

Schutz, A. \& Luckmann, T. (1973). The Structures of The Life-World, Evanston: Northwestern University Press.

Sofuoğlu Kılıç, N. (2012). Toplumsal İlişkiler Alanı olarak Sanal Alem Üzerine Schutzcu Bir Çözümleme, Dokuz Eylül Üniversitesi Sosyal Bilimler Enstitütsü Dergisi, Cilt 13, Sayı:4, 139-150.

Sorokin, P. A. (1942). Man and Society in Calamity: Effetcs of War, Revolution, Famine, Pestilence upon Human Mind, Behavior, Social Organization and Cultural Life, Virginia: William Byrd Press.

Şentürk, Ü. (2020). Bir Çatışma Kaynağı Olarak Afetlerin Değiş̧meye Etkisi. İ. Can (Ed.), Afet Sosyolojisi içinde (ss. 111-121), İstanbul: Çizgi Kitabevi.

Tierney, K. \& Bevc, C. Kuligowski, E. (2006), Metaphors Matter: Disaster Myths, Media Frames, and Their Consequences in Hurricane Katrina, The Annals of the American Academy of Political and Social Science, Vol. 604, Shelter from the Storm: Repairing tht National Emergency Management System afgter the Hurricane Katrina, ss.57-81.

Lindell, M. K., (2013). Disaster Studies, Current Sociology Review, 61(5-6) 797-825, Sage Publications.

Nasreen, M. (2004). Disaster Research: Exploring Sociological Approach to Disaster in Bangladesh, Bangladesh Journal of Sociology, Volume 1. Number 2.

Stallings, R. A. (2002). Weberian Political Sociology and Sociological Disaster Studies, Sociological Forum, Vol.17, No.2., ss. 281-305.

Quarantinelli, E.L. (1972) When Disaster Strikes(It isn't Much Like What You've Heard and Heard About), Psychology Today 5:66-70.

\section{Raporlar}

Depremden 5 Yıl Sonra Düzce İlinde Değișen Toplumsal, Ekonomik Ve Kişisel Yaşam, TÜBİTAK Hızlı Destek Proje Raporu, Prof. Dr. Belkıs Kümbetoğlu Yard. Doç Dr. İnci User Yard. Doç Dr. Şebnem Gülfidan Doç Dr. Betül Yarar Dr. Meziyet Mozakoğlu Melih Çoban ( MA ), Eylül 2007, İstanbul

\section{İnternet Kaynakları}

https://www.afad.gov.tr/afadem/dogal-afetler 


\section{Extended Abstract}

This study intends to provide sociological and methodological contributions which are focused on individual and society. to disaster studies, dominantly analyzed with natural sciences approach and classical disaster appaoraches, . In Turkey, disasters that are focused on earthquake studies and mainly focus on fullfilling necessities after earthquake and preparations to earthquakes are limitedly analyzed within sociological regards. Therefore, it is required to establish not only to earthquakes but also to all disasters' literature and to focus on individual and individuals" "meaning" and reconstruction of "routine". Within this regard, dealing with sociological aspect of disasters and phenomenological and ethnomethodological focusing on "meaning" and "reconstruction" process will make sociological aspect of disaster literature more robust.

Within that regard, this study has focused on analyzing main theoretical aspects of disasters at the beginning. Thus, different explanations of disasters by Dynes, Drabek and Fritz have constituted the main theoretical explanations. At that point, Fritz attitude towards disasters that disasters can function as a laboratory to analyze human beaviors on a scale where routine is distrupted by an unexpected event. This approach contributed to establishing main argument of the study, to utilize disasters as understanding social structure in an atmosphere of chaos and disorder.

Following theoretical framework, disaster literature has been narreted and all pionering studies have been presented to grasp different aspects towards different types of disasters. In addition, effects of disasters upon social change have been discussed through explanations of Bates and Peacock.

Sociological construction of the study has been mainly focused on ethnomethodological and phenomenological approaches by Alfred Schutz and Harold Garfinkel. Ethnomethodological approach by Garfinkel has paid attention to disasters as a tool for breaking the routine. How people behave at unexpected conditions /out of their routine behaviors) can contribute to grasp how people establish new forms of social relationships and social meanings.

Alfred Schutz and his "stock of knowledge" is also another theoretical approach contributed to the study. Schutz argued that, we have grown up with full of stock of knowledge where we do not question whre do they come from. The purposes of the actions of the everyday person, the meaning of those (social) actions, are largely drawn from an inventory of learned, biographically informed, socially oriented, takenfor-granted typifications. Schutz calls this inventory a person's "stock of knowledge at hand". The stock of knowledge at hand signifies the comprehension and architecture of the life-world of the natural attitude. "Bracketing" comes to the forefront at that point. Bracketing should not be merely a term used in a study to justifyor validate an individual's approach or researcher's method but, rather,a rich con-cept that can facilitate effective and needed qualitative research.Bracketing comprises three general but distinct phases. Within each phase, there exist core elements made up of different components. The researcher's theoretical orientation, questions, focus, and emphasis will determine the compositions of these elements. After constructing main framework of the paper, Turkish disaster literature has also been narrated to present main attitudes towards disasters in Turkey. Within that regard, it was discussed that disaster literature in Turkey is mainy based upon earthquakes. Thus, after the most destructive earthquake at August 17, 1999 at Marmara Region of Turkey, literature and studies on earthquakes have rised in drastic numbers. However, nearly all these studies focus on traumatic problems of victims, lack of states' capacity to meet the need of victims, civil societal relations after the earthquake to provide quick research and rescue at disaster zones.

Mostly cited studies of Kasapoğlu and Ecevit that also focus on aftermath of August 17, 1999 at Marmara Region, discusses the impact of disasters on social change, social order and social balance. In addition, Kasapoğlu and Ecevit also emphasize ambiguity and alienation after earthquakes that create serious problems for victims that last for many years. Also,preparation for earthquakes and establishing awareness for disasters constitute one of the most significant parts of disaster studies and official studies by nation-states. Within that regard, studies mainly deal with post-earthquake and rapid studies at destructed areas, interviewing with victims, writing papers on what to do, how to do and recommendations and so on. At the Conclusion part, this paper presents Indexicality as a methodological recommendation which draws attention to the problem of how actors in a context construct a vision of reality in that context. The concept of indexicality thus directs an investigator's attention to actual interactive contexts in order to see how actors go about creating indexical expressionswords, facial and body gestures and other cues to create and sustain the presumption that a particular reality governs their affairs. This indexicality, is thought to provide more robust sociological attitude to disaster studies where only physical and psychological damages have always been studied but sociological meaning and individual construction of the meaning of disasters have always been neglected. 